First Births In America 


\title{
STUDIES IN DEMOGRAPHY
}

\author{
General Editors
}

Eugene A. Hammel

Ronald D. Lee

Kenneth W. Wachter

1. Douglas Massey, Rafael Alarcon, Jorge Durand, Humberto Gonzalez, Return to Aztlan: The Social Process of International Migration from Western Mexico

2. Ronald R. Rindfuss, S. Philip Morgan, Gray Swicegood, First Births in America: Changes in the Timing of Parenthood 


\section{FIRST BIRTHS}

\section{IN AMERICA}

Changes In The Timing

of Parenthood

Ronald R. Rindfuss

S. Philip Morgan

Gray Swicegood

University of California Press / Berkeley, Los Angeles, London 
University of California Press

Berkeley and Los Angeles, California

University of California Press, Ltd.

London, England

Copyright (C) 1988 by The Regents of the University of California

Library of Congress Cataloging-in-Publication Data

Rindfuss, Ronald R., 1946-

First Births in America.

(Studies in demography)

Bibliography: p.

Includes index.

1. Family demography. 2. Parenthood. I. Morgan,

S. Philip, 1953- II. Swicegood, Gray, 1950-

III. Title. IV. Series: Studies in demography

(Berkeley, Calif.)

HQ759.98.R56 1988

$306.8^{\prime} 74$

$87-5073$

ISBN 0-520-05907-7 (alk. paper)

Printed in the United States of America

123456789 